\title{
Biological risks in professionals working in the mobile urgency service
}

\author{
Tatiana de Sousa Sobral Carvalho ${ }^{1}$, Adriana Ferreira Costa ${ }^{2}$, Wanessa Castro Martins ${ }^{3}$, \\ Maria Claudia Gonçalves ${ }^{4}$ and Sílvio Gomes Monteiro ${ }^{5}$
}

\author{
${ }^{1}$ Universidade CEUMA - UniCEUMA, São Luís-Maranhão, Brasil \\ tatinhasobral@hotmail.com \\ ${ }^{2}$ Universidade CEUMA - UniCEUMA, São Luís-Maranhão, Brasil \\ adricaferreirac@gmail.com \\ ${ }^{3}$ Universidade CEUMA - UniCEUMA, São Luís-Maranhão, Brasil \\ wanessacast@hotmail.com \\ ${ }^{4}$ Universidade CEUMA - UniCEUMA, São Luís-Maranhão, Brasil \\ mcgfisio0@gmail.com \\ ${ }^{5}$ Universidade CEUMA - UniCEUMA, São Luís-Maranhão, Brasil \\ silvio_gm@yahoo.com.br
}

\begin{abstract}
This descriptive, cross-sectional study aims to evaluate the biological risks among professionals who work in the Mobile Emergency Service of the Metropolitan Region of São Luis - MA. The data were collected from 177 professionals from basic and advanced support units between February and April 2018, using a structured questionnaire. While a high prevalence of exposure to biological risks was observed among all the subjects, men were found to be at a higher risk. The main source of contamination was blood, mainly affecting the whole skin during the procedure of immobilization. It was evidenced that most of the subjects did not complete the accident report and did not adhere to any post-exposure protocols. It is believed that the development of educational, safety and health measures can minimize the occupational hazards and accidents among the SAMU professionals, who are providers of indispensable service to society, even if susceptible to various environmental risks.
\end{abstract}

Keywords: Emergency medical services; Occupational hazards; Exposure to biological agents 


\section{Introdution}

Accidents at work result in significant morbidity and mortality, and are, therefore, an important public health problem. In Brazil, work-related injuries account for approximately $25 \%$ of all injuries caused by external causes and treated in emergency rooms. They also claim more than $70 \%$ of the accidental benefits from the Social Security (GALDINO, SANTANA and FERRITE, 2012).

Health professionals are exposed to various environmental hazards in their daily lives. These include accidents caused by physical, chemical, and biological agents, as well as ergonomic hazards. These exposures can eventually lead to occupational diseases. Among the healthcare professionals, those working in pre-hospital care (APH) deserve special attention. This specialized service provides direct assistance to patients outside the hospital before they arrive at a nursing home, with the aim of maintaining life and minimizing the sequelae to victims in emergency situations.

According to the Ministry of Health, the urgent and emergency services in Brazil are perceived as poor sectors of the healthcare system and problematic areas of the Unified Health System (SUS), where the decentralization, regionalization and hierarchical guidelines are poorly implemented (MACIAK, SANDRI, SPIER, 2009). The National Emergency Care Policy (PNAU) and the Mobile Emergency Care Service (SAMU) have joined hands with the purpose of structuring the services and thereby improving the organization of the care network. It, therefore, constitutes an important component of the Brazilian healthcare system and plays an essential role in the discussion and analysis of problems with the purpose of proposing effective solutions.

Individuals working with SAMU are exposed to a higher risk of accidents since they work in diverse environments that are usually devoid of planning, such as public roads, residences, beaches and inside ambulances. In addition to unplanned locations, there are factors that impact the development of these services, since the professionals are exposed to stressors and emergency situations, making them vulnerable to constant environmental risks.

Occupational hazards related to potentially contaminated biological materials are caused by direct contact with blood, secretions, excretions, and other bodily fluids infected or not, indirect contact through blood splatters, secretions, excretions and other bodily fluids in the skin and / or mucosa, and from pathogens through contaminated materials and equipment, aerosols and fomites (OLIVEIRA; LOPES; PAIVA, 2009). SAMU professionals are at a high risk of exposure to blood and other biological materials, considering that they provide care for victims of trauma with open and bleeding lesions, with serious or even infectious diseases, often in extremely complex situations, such as the type of trauma and the stress in agility during service (GUIMARÃES et al., 2011).

Accidents with biological materials can transmit HIV and hepatitis B and C among other diseases. The estimated risk will depend on the type of accident and the area of exposure. The use of personal protective equipment (PPE) is essential for the prevention of such transmissions. Post-exposure measures should also be adopted in order to minimize the risk of professionals getting sick, and should start with local care extending to the use of chemoprophylaxis for each pathology (BRASIL, 2010).

Workers in APH provide indispensable service to society, inspite of being susceptible to several environmental risks. This study aims to evaluate the biological risks faced by professionals working for the Mobile Emergency Service in the Municipalities of São Luís, Paço do Lumiar and São José of Ribamar - MA. 


\section{Methods}

\subsection{Study and Data collection}

The present research is characterized as a descriptive and transversal study. It was carried out from February to April 2018, in three municipalities: São Luís, Paço do Lumiar and São José de Ribamar - MA, in three units: SAMU São Luís Regional Center, SAMU Decentralized Base Paço do Lumiar and SAMU Decentralized Base São José de Ribamar. A structured questionnaire was used for data collection, which included questions on sociodemographic variables, characterization of the accident (s) with biological material, and post-exposure clinical follow-up.

For calculating the sample size, we considered the total number of SAMU employees who worked in the basic and advanced support units of the three municipalities $(\mathrm{N}=380)$. In addition, a prevalence of $41.2 \%$ was used, based on a previous study involving accidents with biological materials in APH in Goiânia-GO (TIPPLE et al., 2013), with a 5\% level of significance $(\alpha)$ plus a tolerable error of $8 \%$, and 5\% for possible losses. Finally, 177 professionals were included in the study. Sampling was stratified according to the types of professionals and research sites.

This study was approved by the Local Ethics Committee, according to opinion number 2.469.203.

\subsection{Statistical analysis}

The data were evaluated using the IBM SPSS Statistics 20 (2011) program. The non-parametric qui-square test of independence $\left(\chi^{2}\right)$ was applied to evaluate the association of the various classificatory variables such as the original stocking (São Luís, São José de Ribamar, and Paço do Lumiar). The level of significance to reject the null hypothesis was $5 \%$, that is, a $\mathrm{p}$ value of $\mathrm{p}<0.05$ was considered statistically significant.

\section{Results and discussion}

We interviewed 177 workers from the Metropolitan Region's SAMU, which included 22 doctors, 30 nurses, 61 nursing technicians and 63 drivers. Table 1 summarizes the sociodemographic characteristics of the subjects and their training. The SAMU professionals in the municipality of Paço do Lumiar were predominantly 30 - 39 years old (60\%), while those in the municipalities of São Luís and São José de Ribamar, were 40 - 49 years old (56.5\% and 47.4\% respectively). In Paço do Lumiar, 25\% of the employees were 20 - 29 years old, directly influencing the level of significance among the municipalities $(\mathrm{p}<0.05)$. While $65 \%$ of all participants were married or lived in a consensual union, $45 \%$ of them in the SAMU of Paço do Lumiar were single. Therefore, differences were noted in the age groups and marital status of participants from different municipalities, with younger and single workers concentrated in Paço do Lumiar. A study on SAMU professionals from Campinas-SP, indicated the average age of the participants to be 39 years, most of them being married (VEGIAN; MONTEIRO, 2011).

A higher percentage $(59.3 \%)$ of participants in the three municipalities were men, which corroborates with the results of other studies. Serra (2014), when evaluating pain, quality of life and health among 192 professionals at SAMU, also found a predominance of male professionals, which confirmed the findings of Oliveira and Paiva (2013). The predominance $(63.2 \%)$ of men was also seen when analyzing occupational accidents among pre-hospital care professionals.

With regards to the length of service in the institution, while $84.8 \%$ and $78.9 \%$ of SAMU professionals in São Luís and São José de Ribamar, respectively had been working there more than 5 years, $85 \%$ of the respondents at SAMU in Paço do Lumiar, had been working there for 2-3 years. Dutra (2013), when studying the practices adopted by APH professionals who were victims of occupational accidents with biological materials, identified that the majority of. 
Table 1- Sociodemographic characteristics and training of professionals working in pre-hospital care - SAMU Metropolitan Region, São Luís - MA 2018.

\begin{tabular}{|c|c|c|c|c|c|c|c|}
\hline \multirow{2}{*}{$\begin{array}{c}\text { Professional } \\
\text { Characteristics }\end{array}$} & \multicolumn{6}{|c|}{ Crowded } & \multirow[b]{2}{*}{$\mathbf{p}$} \\
\hline & São Luís & $\%$ & $\begin{array}{l}\text { São José de } \\
\text { Ribamar }\end{array}$ & $\%$ & $\begin{array}{l}\text { Paço do } \\
\text { Lumiar }\end{array}$ & $\%$ & \\
\hline \multicolumn{8}{|l|}{ Age group (years) } \\
\hline $20-29$ & 3 & 2.2 & 1 & 5.3 & 5 & 25.0 & \multirow[t]{4}{*}{0.000} \\
\hline $30-39$ & 34 & 24.6 & 8 & 42.1 & 12 & 60.0 & \\
\hline $40-49$ & 78 & 56.5 & 9 & 47.4 & 3 & 15.0 & \\
\hline$>49$ & 23 & 16.7 & 1 & 5.3 & 0 & 0.0 & \\
\hline \multicolumn{8}{|l|}{ Gender } \\
\hline Female & 58 & 42.0 & 6 & 31.6 & 8 & 40.0 & \multirow[t]{2}{*}{0.684} \\
\hline Male & 80 & 58.0 & 13 & 68.4 & 12 & 60.0 & \\
\hline \multicolumn{8}{|l|}{ Education } \\
\hline Complete Middle & 61 & 44.2 & 7 & 36.8 & 5 & 25.0 & \multirow[t]{3}{*}{0.491} \\
\hline Incomplete higher & 15 & 10.9 & 3 & 15.8 & 4 & 20.0 & \\
\hline Graduated & 62 & 44.9 & 9 & 47.4 & 11 & 55.0 & \\
\hline \multicolumn{8}{|l|}{ Marital status } \\
\hline $\begin{array}{l}\text { Married / Consensual } \\
\text { Union }\end{array}$ & 91 & 65.9 & 13 & 68.4 & 11 & 55.0 & \multirow[t]{4}{*}{0.198} \\
\hline Not married & 28 & 20.3 & 5 & 26.3 & 9 & 45.0 & \\
\hline Separated / divorced & 17 & 12.3 & 1 & 5.3 & 0 & 0.0 & \\
\hline Widower & 2 & 1.4 & 0 & 0.0 & 0 & 0.0 & \\
\hline \multicolumn{8}{|l|}{$\begin{array}{l}\text { Professional } \\
\text { qualification }\end{array}$} \\
\hline Nurse & 22 & 15.9 & 3 & 15.8 & 5 & 25.0 & \\
\hline Doctor & 16 & 11.6 & 3 & 15.8 & 3 & 15.0 & 0.927 \\
\hline Nursing Technician & 50 & 36.2 & 6 & 31.6 & 5 & 25.0 & \\
\hline First aid driver & 50 & 36.2 & 7 & 36.8 & 7 & 35.0 & \\
\hline \multicolumn{8}{|l|}{ Service time (years) } \\
\hline 1 & 1 & 0.7 & 0 & 0.0 & 0 & 0.0 & \multirow[t]{6}{*}{0.000} \\
\hline $1-2$ & 6 & 4.3 & 3 & 15.8 & 0 & 0.0 & \\
\hline $2-3$ & 3 & 2.2 & 0 & 0.0 & 17 & 85.0 & \\
\hline $3-4$ & 6 & 4.3 & 1 & 5.3 & 0 & 0. & \\
\hline $4-5$ & 5 & 3.6 & 0 & 0.0 & 2 & 10.0 & \\
\hline$>5$ & 117 & 84.8 & 15 & 78.9 & 1 & 5.00 & \\
\hline \multicolumn{8}{|l|}{ Salary } \\
\hline $1-2$ & 84 & 60.9 & 13 & 68.4 & 12 & 60.0 & \multirow[t]{5}{*}{0.001} \\
\hline $2-3$ & 16 & 11.6 & 0 & 0.0 & 4 & 20.0 & \\
\hline $3-4$ & 0 & 0.0 & 3 & 15.8 & 1 & 5.0 & \\
\hline $4-5$ & 15 & 10.9 & 0 & 0.0 & 0 & 0.0 & \\
\hline$>5$ & 23 & 16.7 & 3 & 15.8 & 3 & 15.0 & \\
\hline \multicolumn{8}{|l|}{ Unhealthy / Hazardous } \\
\hline Yes & 80 & 58.0 & 19 & 100.0 & 20 & 100.0 & \multirow[t]{2}{*}{0.000} \\
\hline \multirow[t]{2}{*}{ No } & 58 & 42.0 & 0 & 0.0 & 0 & 0.0 & \\
\hline & 138 & 100.0 & 19 & 100.0 & 20 & 100.0 & \\
\hline
\end{tabular}


them had been working for more than 5 years. This duration of employment at SAMU of Paço do Lumiar can be explained by the fact that the service was implemented in 2012, with a public tender for this institution issued in 2014

While $61.6 \%$ of the professionals received one to two wages, only $16.4 \%$ had more than five wages. A significant difference was found in the number of individuals who reported they were unhealthy $(p<0.05)$. While $100 \%$ of the respondents from the municipalities of São José de Ribamar and Paço do Lumiar received a health allowance, only 58\% $(\mathrm{n}=138)$ of the participants from SAMU in São Luís reported having this benefit on their paychecks, and 42\% said they did not receive it. It is important to emphasize that these results are in line with those of other studies. While Costa (2011) found that $21.6 \%$ of the SAMU professionals they evaluated did not receive these benefits, Santini et al. (2009), reported that $58 \%$ of the respondents from family health programs in Paraná did not receive them.

A significant difference $(\mathrm{p}<0.05)$ was observed in the number of accidents among the three municipalities (Figure 1). While in SAMU of Paço de Lumiar 36.4\% of the interviewees suffered more than six accidents, $33.3 \%$ and $38.5 \%$ of the respondents in São Luís and São José de Ribamar, respectively, had just one accident (Figure 1).

Figure 1- Number of biological accidents by different municipalities

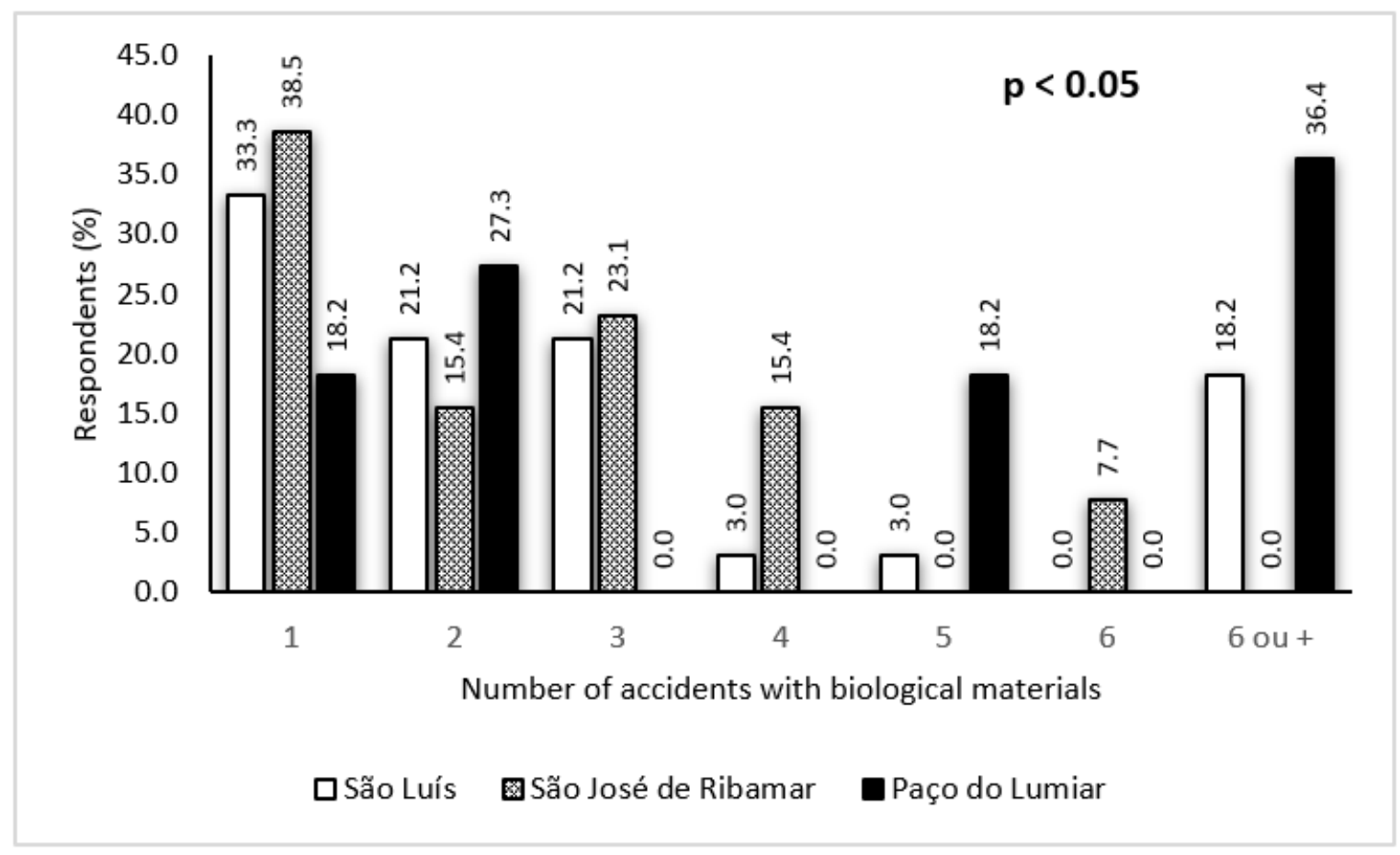

Table 2 shows that in the three municipalities studied, $50.8 \%$ of the participants suffered accidents with biological materials. Of these accidents, the most reported type of exposure was intact skin ( $72.2 \%)$, followed by percutaneous (20\%) and mucosa (7.8\%). The high incidence of accidents with biological materials is compatible with earlier reports (TIPLLE et al., 2013), which demonstrate the need for implementation of special measures to protect workers. Biosafety measures are a way of reducing the existing risks, through educational and preventive actions, (SOUSA, SILVA, 2014). Health professionals worldwide are at an increased risk of contracting pathogens, such as hepatitis B and C viruses, and HIV, when compared to any other occupational groups (GORAR, BUTT, AZIZ, 2014). 
Table 2 - Distribution of accidents with biological materials in SAMU professionals.

\begin{tabular}{|c|c|c|c|c|c|c|c|}
\hline \multirow{2}{*}{$\begin{array}{c}\text { Accidents with Biological } \\
\text { Materials }\end{array}$} & \multicolumn{6}{|c|}{ Crowded } & \multirow[t]{2}{*}{$\mathbf{p}$} \\
\hline & $\begin{array}{c}\text { São } \\
\text { Luís }\end{array}$ & $\%$ & $\begin{array}{l}\text { São José de } \\
\text { Ribamar }\end{array}$ & $\%$ & $\begin{array}{l}\text { Paço do } \\
\text { Lumiar }\end{array}$ & $\%$ & \\
\hline \multicolumn{8}{|l|}{ Biological accident } \\
\hline Yes & 65 & 47.1 & 13 & 68.4 & 11 & 55.0 & \multirow[t]{2}{*}{0.198} \\
\hline No & 73 & 52.9 & 6 & 31.6 & 9 & 45.0 & \\
\hline \multicolumn{8}{|l|}{ Amount } \\
\hline 1 & 22 & 33.3 & 5 & 38.5 & 2 & 18.2 & \multirow[t]{7}{*}{0.021} \\
\hline 2 & 14 & 21.2 & 2 & 15.4 & 3 & 27.3 & \\
\hline 3 & 14 & 21.2 & 3 & 23.1 & 0 & 0.0 & \\
\hline 4 & 2 & 3.0 & 2 & 15.4 & 0 & 0.0 & \\
\hline 5 & 2 & 3.0 & 0 & 0.0 & 2 & 18.2 & \\
\hline 6 & 0 & 0.0 & 1 & 7.7 & 0 & 0.0 & \\
\hline More than 6 & 12 & 18.2 & 0 & 0.0 & 4 & 36.4 & \\
\hline \multicolumn{8}{|l|}{ Last type of exposure } \\
\hline Percutaneous & 13 & 19.7 & 2 & 15.4 & 3 & 27.3 & \multirow[t]{3}{*}{0.961} \\
\hline Mucosa & 5 & 7.6 & 1 & 7.7 & 1 & 9.1 & \\
\hline Whole skin & 48 & 72.7 & 10 & 76.9 & 7 & 63.6 & \\
\hline \multicolumn{8}{|l|}{ Organic material } \\
\hline Blood & 65 & 98.5 & 10 & 76.9 & 11 & 100.0 & \multirow[t]{2}{*}{0.001} \\
\hline Liquor & 1 & 1.5 & 0 & 0.0 & 0 & 0.0 & \\
\hline Other & 0 & 0.0 & 3 & 23.1 & 0 & 0.0 & \\
\hline \multicolumn{8}{|l|}{ Activity exercised } \\
\hline Medication administration & 3 & 4.5 & 0 & 0.0 & 0 & 0.0 & \multirow[t]{8}{*}{0.367} \\
\hline Venous / arterial puncture & 8 & 12.1 & 1 & 7.7 & 2 & 18.2 & \\
\hline $\begin{array}{l}\text { Inadequate disposal of sharp } \\
\text { material in mattress, countertop, floor }\end{array}$ & 3 & 4.5 & 0 & 0.0 & 1 & 9.1 & \\
\hline Laundry & 0 & 0.0 & 0 & 0.0 & 1 & 9.1 & \\
\hline Band Aid & 4 & 6.1 & 0 & 0.0 & 0 & 0.0 & \\
\hline Capillary glycemia & 4 & 6.1 & 1 & 7.7 & 0 & 0.0 & \\
\hline Immobilization & 37 & 56.1 & 8 & 61.5 & 7 & 63.6 & \\
\hline Other (intubation) & 7 & 10.6 & 3 & 23.1 & 0 & 0.0 & \\
\hline \multicolumn{8}{|l|}{ Location of the accident } \\
\hline Advanced Support Unit & 28 & 42.4 & 6 & 46.2 & 7 & 63.6 & \multirow[t]{5}{*}{0.000} \\
\hline Basic Support Unit & 38 & 57.6 & 2 & 15.4 & 3 & 27.3 & \\
\hline In public & 0 & 0.0 & 4 & 30.8 & 0 & 0.0 & \\
\hline In the patient's home & 0 & 0.0 & 1 & 7.7 & 0 & 0.0 & \\
\hline At the base or point of support & 0 & 0.0 & 0 & 0.0 & 1 & 9.1 & \\
\hline \multicolumn{8}{|l|}{ Work shift } \\
\hline Daytime & 39 & 59.1 & 3 & 23.1 & 4 & 36.4 & \multirow[t]{2}{*}{0.035} \\
\hline Night & 27 & 40.9 & 10 & 76.9 & 7 & 63.6 & \\
\hline \multicolumn{8}{|l|}{ Work schedule } \\
\hline Normal schedule & 66 & 100.0 & 12 & 92.3 & 11 & 100.0 & \multirow[t]{2}{*}{0.050} \\
\hline Change of duty & 0 & 0.0 & 1 & 7.7 & 0 & 0.0 & \\
\hline
\end{tabular}


The number of accidents with biological material among the municipalities is worth mentioning because, while in São Luís and São José de Ribamar an average of one accident was reported among the first responders, it was more than six accidents in Paço do Lumiar. It should be emphasized that the employees of this unidad of mobile emergency care service, had two to three years of acting. Tavares et al. (2016) as well as Machado and Machado (2011), have shown that the highest accident rates were related to shorter work experience, and the most exposed workers were those with up to five years of service. In contrast, Pimenta et al. (2013) found that workers with 11 - 20 years of experience were most prone to accidents involving biological materials.

The organic material variable was significantly different in the region São José de Ribamar compared to the other regions ( $p=0.001)$. Blood contamination was most prevalent among professionals $(95.5 \%)$, occurring mainly during activities such as immobilizations (57.8\%) and venous punctures (12.2\%). A study on professionals from SAMU of Teresina - PI found blood to be the predominant biological material in accidents (89.9\%) (Leite et al., 2016). The same was found in four municipalities in the State of Minas Gerais, wherein blood was evidenced in $90.3 \%$ of the accidents at work related to contact with body fluids (OLIVEIRA; PAIVA, 2013).

In pre-hospital care, professionals are constantly exposed to various occupational hazards, especially when directly and indirectly handling body secretions of patients with unknown diseases, and they can become a source of transmission for themselves and / or other victims (MOURA, 2011). Gomes and Santos (2012), when studying the frequency of work accidents among mobile pre-hospital care teams, found that these accidents frequently occurred during immobilizations. A significant difference $(\mathrm{p}=0.000)$ was detected in the accident sites with biological materials between São José de Ribamar, and Paço do Lumiar. These municipalities had a higher frequency of accidents in the Advanced Support Unit - USA (46.2\% and 63.6\%), but in São Luís the phenomenon was divergent, accidents being more common in the Basic Support Unit (57.6\%).

With regards to working hours, night shifts were more common in São José de Ribamar, and Paço do Lumiar (76.9\% and 63.6\%, respectively), while day shifts were common in São Luís $(59.1 \%)(p=0.03)$.

Table 3 shows that most of the subjects (83.3\%) did not complete the Work Accident Communication (CAT) form. When asked about the conduct at the time of the accident, $81.1 \%$ stated that they had not adhered to any protocol. In addition to post-exposure measures, all work accidents are to be notified and a Work Accident Communication (CAT) submitted. The CAT is a document that informs the INSS that the worker has suffered an accident or is suspected to have acquired an illness at work, and is provided as per the Article 169 of the Consolidation of Labor Laws (CLT) and Law 8.213 / 1991 (Law on Social Security Benefit Plans) (BRAZIL, 2013). In São Luís, 57.6\% of the respondents alleged that the reason for non-notification was the non-valuation of the accident. It was verified that, in the other municipalities in this study, the professionals declared no routine protocol for notification $(p<0.05)$. These data are consistent with other studies that have also found a high incidence of underreporting (Giancott et al., 2004). Underreporting may be related to the lack of specialized service in labor institutions. Another concerning factor is that, even though one of the municipalities in the study, had the occupational health sector within its facilities, yet the professionals claimed that the reason for non-notification was associated with non-valuation of the accident.

As for Hepatitis B vaccination, $96.66 \%$ of the professionals who were exposed to contamination with organic materials reported being vaccinated. This data was similar to that found in a survey carried out in a reference center for the care of workers who suffered industrial accidents in Paraná, wherein $90.1 \%$ of the workers declared that they had received the three-dose schedule of the hepatitis B vaccine (ARANTES et al., 2017). In analyzing whether employees received any educational intervention on biological materials, it was concluded that $81.9 \%$ in São Luís and 78.9\% in São 
José de Ribamar were informed. On the other hand, in Paço do Lumiar, 85\% stated that they received no guidance on the subject $(\mathrm{p}<0.05)$ (Figure 2). It is interesting to observe an association between the numbers of accidents with biological material and the educational interventions on biosafety. The municipality of Paço do Lumiar, which had the least amount of trained personnel, had the largest number of accidents with biological materials (Figure 1). This underscores the importance of the training for all SAMU employees.

Table 3 - Distribution of study variables based on the clinical follow-up of professionals exposed to biological materials

\begin{tabular}{|c|c|c|c|c|c|c|c|}
\hline \multirow{2}{*}{$\begin{array}{l}\text { Conduct after exposure to } \\
\text { biological materials }\end{array}$} & \multicolumn{6}{|c|}{ Crowded } & \multirow[t]{2}{*}{$\mathbf{p}$} \\
\hline & $\begin{array}{l}\text { São } \\
\text { Luís }\end{array}$ & $\%$ & $\begin{array}{c}\text { São José } \\
\text { de } \\
\text { Ribamar }\end{array}$ & $\%$ & $\begin{array}{c}\text { Paço } \\
\text { do } \\
\text { Lumiar } \\
\end{array}$ & $\%$ & \\
\hline \multicolumn{8}{|l|}{ Filled CAT tab } \\
\hline Yes & 12 & 18.2 & 2 & 15.4 & 1 & 9.1 & 0.749 \\
\hline No & 54 & 81.8 & 11 & 84.6 & 10 & 90.9 & \\
\hline \multicolumn{8}{|l|}{ Was notified } \\
\hline none & 52 & 78.8 & 11 & 84.6 & 10 & 90.9 & \multirow[t]{3}{*}{0.579} \\
\hline Some & 8 & 12.1 & 2 & 15.4 & 0 & 0.0 & \\
\hline All & 6 & 9.1 & 0 & 0.0 & 1 & 9.1 & \\
\hline \multicolumn{8}{|l|}{ Reason for Non-notification } \\
\hline Not knowing the need & 7 & 11.9 & 2 & 18.2 & 0 & 0.0 & \multirow[t]{4}{*}{0.000} \\
\hline $\begin{array}{c}\text { Did not appreciate the } \\
\text { accident. }\end{array}$ & 34 & 57.6 & 1 & 9.1 & 1 & 9.1 & \\
\hline No notification routine & 0 & 0.0 & 8 & 72.7 & 10 & 90.9 & \\
\hline Other & 18 & 30.5 & 0 & 0.0 & 0 & 0.0 & \\
\hline \multicolumn{8}{|l|}{ Hepatitis B Vaccine } \\
\hline Vaccinated & 65 & 98.5 & 12 & 92.3 & 10 & & \multirow[t]{3}{*}{0.199} \\
\hline Incomplete layout & 0 & 0.0 & 1 & 7.7 & 1 & 9.1 & \\
\hline Not vaccinated & 1 & 1.5 & 0 & 0.0 & 0 & 0.0 & \\
\hline \multicolumn{8}{|l|}{$\begin{array}{l}\text { Conduct post exposure with } \\
\text { Biological Materials }\end{array}$} \\
\hline $\begin{array}{l}\text { No indication of } \\
\text { chemoprophylaxis }\end{array}$ & 7 & 10.6 & 2 & 15.4 & 2 & 18.2 & \multirow[t]{4}{*}{0.154} \\
\hline Refused prophylaxis & 0 & 0.0 & 0 & 0.0 & 1 & 9.1 & \\
\hline Indicated AZT + 3TC & 6 & 9.1 & 0 & 0.0 & 0 & 0.0 & \\
\hline $\begin{array}{l}\text { You have not adhered to any } \\
\text { protocol }\end{array}$ & 53 & 80.3 & 11 & 84.6 & 9 & 81.8 & \\
\hline \multicolumn{8}{|c|}{ Educational intervention on biosafety } \\
\hline Yes & 113 & 81.9 & 15 & 78.9 & 3 & 15.0 & \multirow[t]{2}{*}{0.000} \\
\hline No & 25 & 18.1 & 4 & 21.1 & 17 & 85.0 & \\
\hline
\end{tabular}

The Center for Permanent Education (NEP) was very active in the municipalities of São Luís and São José de Ribamar, while in Paço do Lumiar, no clear guidelines were made available. As mentioned by the professionals, the lack of training may be related to the absence of an NEP in this service. This finding alerts to the existence of a gap which needs to be filled by the NEP, as well as, by the managers of the SAMU teams. By building a knowledge database, it is possible to plan and execute protective measures (Oliveira, 2015). According to Bueno and Bernardes (2010), permanent education is structured from the needs of the work process, providing the transformation of the practices in order to result in changes. 
Figure 2- Educational intervention on biosafety for SAMU staff

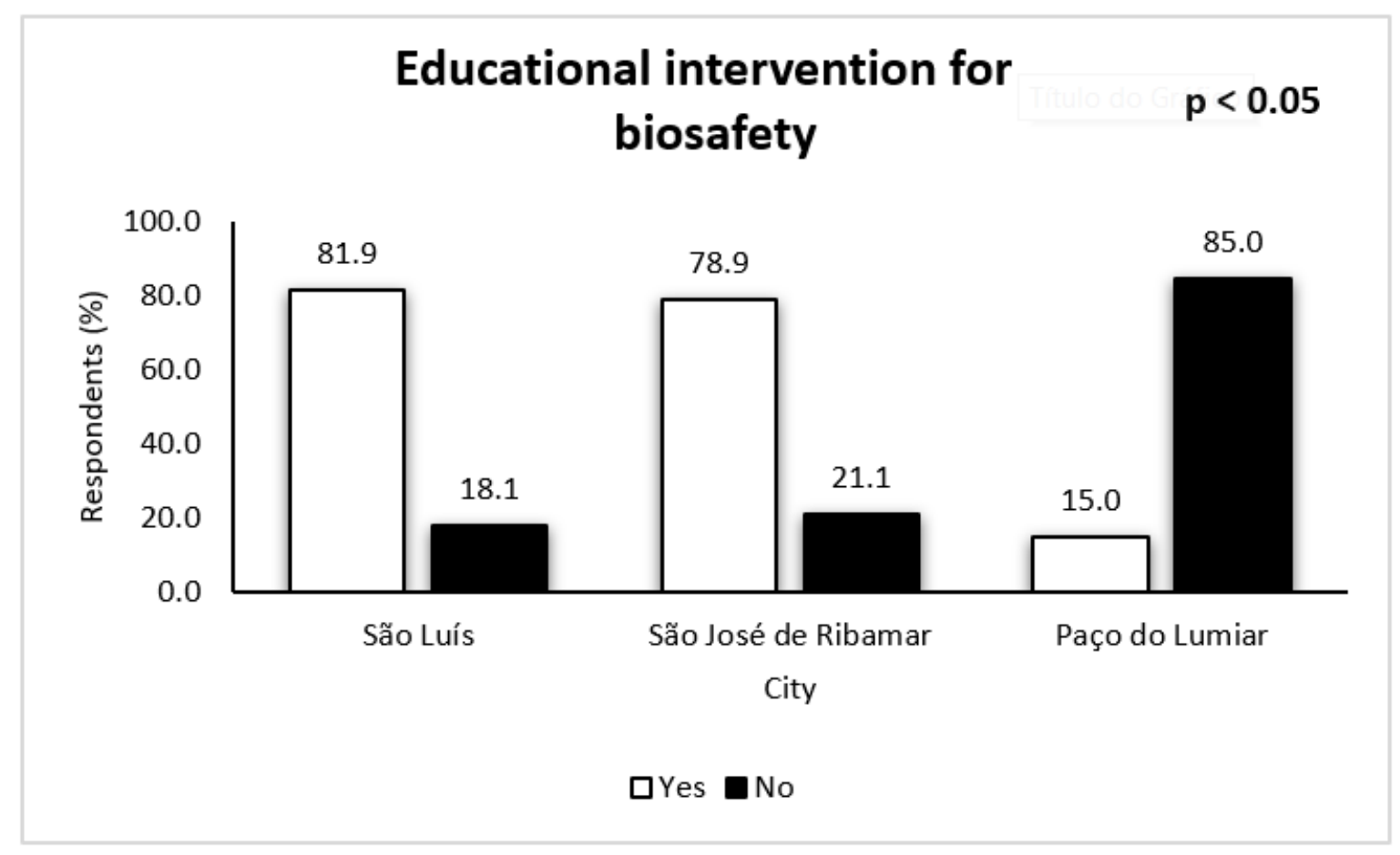

\section{Conclusions}

Based on our findings that confirm the prevalence of accidents involving biological materials among all professional categories (physicians, nurses, nursing technicians and drivers) in different municipalities, it is evident that the work process in the Mobile Emergency Care Service requires to be carefully reexamined.

The problem of contamination while working with blood and the absence of communication regarding these accidents is concerning, considering that education centers existed in two institutions (SAMU São Luís and São José de Ribamar), and the professionals reported that they had participated in training on biological risks. Though SAMU of São Luís, has a labor medicine sector in its dependencies, employees claim that the notifications are neglected due to the nonvaluation of the accident. In other municipalities, it was reported that there are no routine protocols for notifications.

The results of this research reinforce the need to establish strict guidelines and measures to (a) prevent occupational accidents especially those involving biological materials, which are potentially preventable, and (b) to protect the workers once the accident has taken place. Use of personal protective equipment and the development of strategies for adherence to post-exposure care flow can minimize the underreporting of cases and other health hazards. The present study offers subsidies to health professionals, managers and other individuals collaborating for the development of educational, and occupational health actions, aiming to improve the safety of SAMU workers whose services are indispensable for the society.

\section{Acknowledgments}

We thank the Ceuma University - MA, the Mobile Emergency Service of São Luís and the Decentralized Bases of Paço do Lumiar and São José de Ribamar. 


\section{References}

ARANTES, M. C.; HADDAD, M. do C. F. L.; MARCON, S. S.; ROSSANEIS, M. A,; PISSINATI, P. de S. C.; OLIVEIRA, S. A. de. Acidentes de trabalho com material biológico em trabalhadores de serviços de saúde. Cogitare Enferm. Jan/mar; 22(1): 01-08. 2017.

BRASIL. Ministério da Saúde. Recomendações para Atendimento e Acompanhamento de Exposição Ocupacional a Material Biológico: HIV e Hepatites B e C. Brasília: Ministério da Saúde, 2010.

BRASIL. Ministério da Previdência Social. Comunicação de Acidentes de Trabalho. Brasília, 2013.

BUENO, A. A.; BERNARDES, A. Percepção da equipe de enfermagem de um serviço de atendimento pré-hospitalar móvel sobre o gerenciamento de enfermagem. Texto e Contexto - Enfermagem. Florianópolis, v. 19, n. 1, p.45-53, mar. 2010.

COSTA, I. K. F. Riscos ocupacionais e acidentes de trabalho em um serviço de atendimento móvel de urgência do Rio Grande do Norte. 218 f. Dissertação (Mestrado em Assistência à Saúde) - Universidade Federal do Rio Grande do Norte, Natal, 2011.

DUTRA, C. M. Condutas adotadas por profissionais do atendimento pré-hospitalar vítimas de acidentes ocupacional com material biológico em uma cidade do triângulo mineiro. Dissertação de Mestrado. Cíntia Dutra Machado. Enfermagem de Ribeirão Preto/USP. Ribeirão Preto, 2013.

GALDINO, A.; SANTANA, V. S.; FERRITE, S. Os Centros de Referência em Saúde do Trabalhador e a notificação de acidentes de trabalho no Brasil. Cad. Saúde Pública, Rio de Janeiro, 2012.

GUIMARÃES, E. A. de A.; ARAÚJO, G. D.; BEZERRA, R.; SILVEIRA, R. C. DA.; OLIVEIRA, V. C. DE. Percepção de técnicos de enfermagem sobre o uso de equipamentos de proteção individual em um serviço de urgência. Cienc. enferm. 17(3):113-123. dez, 2011.

GOMES, B. B.; SANTOS, W. L. Acidentes laborais entre equipe de atendimento pré-hospitalar móvel (bombeiros/ SAMU) com destaque ao risco biológico. Revista; 1(1): 40-49 - Jan/Jun 2012.

GORAR, Z. A.; BUTT, Z. A.; AZIZ, I. Risk factors for bloodborne viral hepatitis in healthcare workers of Pakistan: a population based case-control study. BMJ Open [Internet]. 2014[cited 2015 Nov 07]; 4 (7): e004767. Available from: http://bmjopen.bmj.com/content/4/7/e004767.

LEITE, H. D. C. S.; CARVAlho, M. T. R. de.; CARIMAN, S. L. da S.; ARAúuO, E. R. de M.; SiLVA, N. C.; CARVALHO, A. de O. Risco ocupacional entre profissionais de saúde do Serviço de Atendimento Móvel de Urgência - SAMU. Revista Enferm. Foco. (3/4): 31-35, 2016.

MACHADO, M. R. M.; MACHADO, F. A. Acidentes com material biológico em trabalhadores de Enfermagem do Hospital Geral de Palmas (TO). RBSO, v.36, n.124, p.274-281, 2011.

MACIAK, I.; SADRI, J.; SPIER, F. Humanização da assistência de enfermagem em uma unidade de emergência: percepção do usuário. Cogitare enferm. 14(1): 127-35. 2009.

GIANCOTTI, G. M.; HAEFFNER, R.; SOlHEID, N. L. dos S.; MIRANDA, F. M. D. A.; SARQUIS, L. M. M. Caracterização das vítimas e dos acidentes de trabalho com material biológico atendidas em um hospital público do Paraná. Universidade Federal do Paraná. 2012.

MOURA, M. A. A. M. Nível de informação sobre biossegurança dos profissionais de saúde no pré-hospitalar / Márcio Alex de Almeida Moura (Dissertação). Mestrado em Saúde Coletiva, Universidade Sagrado Coração, Bauru - SP, 2011

OLIVEIRA, A. C.; LOPES, A. C. S.; PAIVA, M. H. R. S. Acidentes ocupacionais por exposição a material biológico entre a equipe multiprofissional do atendimento pré-hospitalar. Rev. Esc. Enferm. USP. set; 43(3): 67783. 2009. 
OLIVEIRA, A. C.; PAIVA, M. H. R. S. Análise dos acidentes ocupacionais com material biológico entre profissionais em serviços de atendimento pré-hospitalar. Rev. Latino-Am. Enfermagem jan.-fev. 2013.

OLIVEIRA, J. A. N. Avaliação de riscos ergonômicos nos profissionais de enfermagem do Serviço e Atendimento Móvel de Urgência - Samu/Recife / Jacqueline Augusta do Nascimento Oliveira. - Recife, 2015. 162 f.: il., fig. Orientador: Marcelo Márcio Soares. Dissertação (Mestrado) - Universidade Federal de Pernambuco. Centro de Artes e Comunicação. Design, 2015.

PIMENTA, F. R.; FERREIRA, M. D.; GIR, E.; HAYASHIDA, M.; CANINI, S. R. M. S. Atendimento e seguimento clínico especializado de profissionais de enfermagem acidentados com material biológico. Rev. esc. enferm. USP [online]. vol.47, n.1, pp.198-204. ISSN 0080-6234. 2013. http://dx.doi.org/10.1590/S0080-62342013000100025.

SANTINI, S. M. L.; JEDLICZKA, J. R. S.; NUNES, E. F. P. A.; BORTOLETTO, M. S. S. Perfil dos profissionais das equipes de saúde da família em municípios de pequeno porte de uma regional de saúde do Paraná e suas condições de trabalho. III Congresso Consad de Gestão Pública. Disponível em: < http://www.escoladegestao.pr.gov.br/arquivos/File/ Material_\%20CONSAD/paineis_III_congresso_consad/painel_3/Perfil_dos_profissionais_das_equipes_de_saude_da_ familia_em_municipios_de_pequeno_porte_de_uma_regional_de_saude_do_parana_e_suas_condicoes_de_trabalho. pdf; 2009 Acesso em 12/06/2018.

SERRA, R. A. Dor, qualidade de vida e saúde dos profissionais do SAMU-192. Universidade Católica Dom Bosco [Dissertação]. Rodrigo Aranda Serra, Mestrado em Psicologia, Campo Grande, MS, 2014.

SOUSA, L. P. T.; DA SILVA, M.A. Produção científica da enfermagem sobre acidentes com material biológico. Estudos, Goiânia [Internet] 2014;41 (n. esp) [acesso em 16 jun 2018]. Disponível: http://dx.doi.org/10.18224/est.v41i0.3809.

TAVARES, A. da S.; SOUSA, L. R. M.; SOUSA, G. A. de.; SILVA, I. C. B.; VELOSO, L. U. P.; MOREIRA, W. C. Caracterização de acidentes ocupacionais pela exposição à material biológico em estado do nordeste brasileiro. Rev. Interd. v. 9, n. 2, p. 21-28, abr. mai. jun. 2016.

TIPPLE, A. F. V.; SILVA, E. A. C.; TELES, S. A.; MENDONÇA, K. M.; SOUZA, A.C.S.; MELO, D.S. Acidente com material biológico no atendimento pré-hospitalar móvel: realidade para trabalhadores da saúde e não saúde. Rev. Bras. enferm. v.66, n.3, p.378-84, 2013.

VEGIAN, C. F. L.; MONTEIRO, M. I. Condições de vida e trabalho de profissionais de um serviço de Atendimento Móvel de Urgência. Rev. Latino-Am. Enfermagem. Jul-ago. 2011. www.eerp.usp.br/rlae. 